\title{
Optimal swim speeds by respirometer: an analysis of three neotropical species
}

\author{
Hersília de Andrade e Santos ${ }^{1}$, Edna Maria de Faria Viana ${ }^{2}$, Paulo Santos Pompeu ${ }^{3}$ and \\ Carlos Barreira Martinez ${ }^{2}$
}

The swimming ability of neotropical fish species is an important aspect for fish ladder designs. Especially in Latin America, where fish ladders are highly selective, fish strategies to negotiate the passage should be studied focusing on target species. This paper shows the swimming ability of three neotropical species (Leporinus reinhardti, Pimelodus maculatus and Prochilodus costatus), from São Francisco river basin. Respirometer was employed for data collection. Regarding the critical and prolonged speeds, L. reinhardti was the fastest among the three neotropical species in relative values (body length/ second). The performance of neotropical species was better when compared to critical and maximum prolonged speeds of fish species from temperate areas. Finally, regarding the experimental procedures, the optimization of swimming speed in respirometer is lower than the optimal processes obtained with free swimming in open channels.

A capacidade natatória das espécies neotropicais de peixes é um importante aspecto a ser considerado em projetos de passagem para peixes. Especialmente na América Latina, aonde as passagens para peixes apresentam alta seletividade, estratégias para vencer barreiras de velocidade devem ser estudadas para espécies alvo. Este trabalho levantou a capacidade natatória de três espécies de peixes neotropicais (Leporinus reinhardti, Pimelodus maculatus e Prochilodus costatus) da bacia do rio São Francisco. Foi empregado o método forçado com uso de um em respirômetro. A comparação da velocidade entre as três espécies permitiu concluir que o $L$. reinhardti foi a espécie com maior velocidade crítica e velocidade prolongada em termos relativos (comprimentos/segundo). As espécies neotropicais foram mais rápidas, em termos relativos, do que as espécies de regiões temperadas, considerando velocidade crítica e máxima velocidade prolongada. Com relação aos procedimentos para determinação da capacidade natatória, verificou-se que a otimização da velocidade pelos peixes em respirômetro é inferior a desenvolvida em testes voluntários em canais abertos.

Key words: Fish ladders, Leporinus reinhardti, Pimelodus maculatus, Prochilodus costatus, Swimming ability.

\section{Introduction}

Latin American experience in fish ladders has shown a high selectivity for certain species and a limited success (Clay, 1995; Agostinho et al., 2007). These passes are generally unsuitable for the species concerned. American or European projects with salmonids provided guidelines for fish ladder designs in Latin America and most often they are based on less-than-optimal design criteria (Marmula, 2001). Direct and indirect evidence suggests that South American fish select their swim path primarily using hydrodynamic cues or bedform shape as the North American fish (Baigun et al., 2007). However, important aspects are different, such as temperature and food available, which can determine different responses of swimming abilities.
Fish swimming speed can be divided into three categories: sustained, burst and prolonged speeds (Beamish, 1978). Sustained swimming consists of a spectrum of swimming speeds that can be maintained for an indefinite time period, longer than $200 \mathrm{~min}$, and fatigue is not involved. Burst swimming involves rapid movements of short duration, less than 15-20 seconds, high speeds and anaerobic processes. Prolonged swimming consists of a spectrum of speeds between burst and sustained and has more often been measured in the laboratory. The main subcategory is the critical speed, which was first defined and employed by Brett (1964) and can be defined as the highest swimming speed that a fish can maintain for a time period which is the same of that one used in the test (Peake et al., 2004).

\footnotetext{
${ }^{1}$ Departamento de Engenharia Civil, Centro Federal de Educação Tecnológica de Minas Gerais. Av. Amazonas, 7675, 30510-000 Belo Horizonte, MG, Brazil. hsantos@civil.cefetmg.br

${ }^{2}$ Universidade Federal de Minas Gerais, Centro de Pesquisas Hidráulicas. Av. Antônio Carlos, 6627, 31270-901 Belo Horizonte, MG, Brazil.

${ }^{3}$ Universidade Federal de Lavras, Departamento de Biologia, Ecologia, 37200-000 Lavras, MG, Brazil.
} 
The critical and prolonged speeds are mostly studied by non-volitional techniques. Most information relating to the swimming ability has been provided by studying individuals forced to perform in swim tunnel respirometers (Hammer 1995), whose system also measures the oxygen consumption (Cech, 1990). Despite its wide application in swimming studies, values of measured speed by forced experiments underestimate the voluntary locomotor ability and fish behavior in the field (Mallen-Cooper, 1992; Peake, 2004).

Volitional swimming has supported theories of swim speed optimization (Castro-Santos, 2005) although this kind of experiment requests big investments in channels and tagsystem to obtain swimming speed. The optimal speed, which is defined as the speed at which total energy expenditure per unit distance traveled is minimal, can be obtained by a simplified model of swimming efficiency (Webb, 1975). The log-linear models (1) and (2) provide the value of optimal groundspeed $\mathrm{U}_{\text {gopt }}$ (Castro-Santos, 2005):

$$
\begin{aligned}
& \ln T=a+b U_{s} \\
& U_{\text {gopt }}=-1 / b
\end{aligned}
$$

where $T$ is fatigue time, $U_{\mathrm{s}}$ is relative swimming speed (in body length/s - BL/s), $a$ and $b$ are the intercept, and slope coefficients, respectively. $U_{\text {gopt }}$ is the optimal groundspeed;

According to Castros-Santos (2005), in addition to the fish achieving the optimal swimming speed, it can maximize the swimming distance related to the ground. The ability of fish to approximate the predicted distance-maximizing behaviors is an important fish strategy to guide for the design of fish ladders (Castro-Santos, 2005) as well as the knowledge of fish behavior in water speed field (Katopodis, 1992). For a good bypass design, it is important to understand and forecast the response of an individual fish to the sequence of hydraulic conditions it encounters as it approaches the dam (Anderson, 1988). Therefore, the aims of this study were: (1) to obtain the prolonged and critical speed for three neotropical species by respirometer; (2) to compare their swimming ability to other species from other continents and (3) to analyze if there is an optimization of swimming speed in respirometers.

\section{Material and Methods}

\section{Selected species}

Three species of the São Francisco basin, which is the third largest basin in Brazil, were chosen: Prochilodus costatus, Leporinus reinhardti and Pimelodus maculatus. Fish of these genera are considered target species in fish passes designs. They have a wide distribution in Brazilian basins and their presence is frequently common downstream dams (Pompeu \& Martinez, 2006; Fernandez et al., 2007; Alves, 2007). The knowledge of P. costatus swimming ability is especially important because Prochilodontids constitutes a large proportion of catches, among the characins in Latin America (Marmulla, 2001), and no information on their swimming performance is currently available.

Prochilodus costatus and Leporinus reinhardti are species of characins with migratory habits and relevant fishing importance in Brazilian rivers. They play an important ecological role in the ecosystem (Carvalho-Costa et al., 2008). Pimelodus maculatus is a siluroid which is widely distributed and abundant in the Prata and São Francisco basins. It also has a great importance in commercial fisheries (Welcomme, 1985).

Prochilodus costatus, Leporinus reinhardti and Pimelodus maculatus individuals were caught in the São Francisco River (Minas Gerais State) and remained in observation areas in the laboratory for at least 24 hours with water temperature ranging from $27^{\circ} \mathrm{C}$ to $29^{\circ} \mathrm{C}$. Each fish remained in the laboratory for no longer than 7 days before being tested because of the loss of its swimming ability. Considering the purpose of the study, fish individuals were selected with total length close to the size of first maturation estimated for the Três Marias region. After testing, fish were returned to the river, in the same location where they had been caught.

\section{Respirometer and tests}

The experimental apparatus used to measure swimming ability was based on the respirometer developed by Brett (1964). Tests with Leporinus reinhardti and Pimelodus maculatus used a hydrodynamic tube with $150 \mathrm{~mm}$ nominal diameter and the experiments with Prochilodus costatus occurred in respirometer of $250 \mathrm{~mm}$. Their central part is a chamber made of Plexiglas which allows visualizing the fish. The flow is driven by two centrifugal pumps with water taken from a reservoir. More details can be found in Santos (2007).

In the beginning of test, the fish were put inside the respirometer, which was operated with low discharge to allow the fish to adapt to the new conditions. After 10 minutes, the water speed was increased in steps of $5 \mathrm{~cm} / \mathrm{s}(D V)$, each lasting 5 minutes $(D t)$. These values of increment were based on the possibilities of speed control permitted by the apparatus and the total time of test. After repeating speed increases, the fish would no longer resist the flow. This point was considered the fish fatigue because they could no longer stay in the test section, after several attempts of explosion. The time, which the fish swam in such speed $\left(V_{\max }\right)$ until their fatigue, was then measured.

The critical speed tests, or increasing speed tests, were performed based on the experimental procedure described by Brett (1964). Experiments were conducted between January 2005 and February 2007.

The prolonged speed tests, or fixed speed tests, were based on the methodology used by Brett (1967) and Jones et al. (1974). Each fish was initially submitted to a flow of $0.20 \mathrm{~m} / \mathrm{s}$ for 10 minutes. Following this, a gradual raise was performed to reach the desired speed, in a maximum of 12 minutes. Henceforth, a stop watch was started in order to measure the fatigue time, in a test with a maximum duration of 200 minutes. This swimming time was adopted as it is 
considered the limit between prolonged speed and sustained speed (Beamish, 1978). In survival analysis statistical test, data reaching the limit of 200 minutes were considered the censored information.

During each test performed, parameters concerning the water quality such as dissolved oxygen $(\mathrm{mg} / \mathrm{l})$, temperature $\left({ }^{\circ} \mathrm{C}\right)$, and $\mathrm{pH}$, were monitored every 5 minutes. After the tests, each fish was weighed $(\mathrm{g})$ and measured (total and standard lengths, maximum height and maximum width - $\mathrm{cm}$ ). Equipment was a simple meter and a weight scale. The solid blocking effect was corrected according to Rae \& Pope (1966) and additional details about this correction have been previously published (Santos et al., 2007).

\section{Data analysis}

Data on critical speed and on fish length were transformed into their natural logarithm in order to obtain linear regressions. For data on prolonged speed, survival analysis was used with Kaplan-Meier estimator and regression models (exponential, lognormal and normal) were applied to speed at which the fish swam and the natural logarithm of the test time. Censored data was considered as the fish failure to fatigue, which means it swam for more than 200 minutes in the respirometer.

According to Castro-Santos (2005), the optimal ground speed (2) can be obtained by regression model coefficients (1). After determining the best regression models, the optimal ground speed in prolonged mode was calculated.

The survival curves were carried out for each species prolonged data and compared by two- sample test of Gehan's Wilcoxon. It is a non-parametric test to compare survival functions adapted to censored data and uses the same weight for all individuals (Colosimo \& Giolo, 2006). Statistical significance was indicated by P-values of 0.05 or less. All analyses were performed using the Statistica software (StatSoft, 2007).

\section{Results}

The total length of the fish tested was close to the values of first maturation size (Table 1): $12.9 \mathrm{~cm}$ for Leporinus reinhardti (Rizzo et al., 1996), $19 \mathrm{~cm}$ for Pimelodus maculatus (Santos et al., 2008) and $29 \mathrm{~cm}$ for Prochilodus costatus (Santos et al., 2007b).

Regarding the critical speed, experiments with Leporinus reinhardti and Pimelodus maculatus show a significant relationship between this speed and the total length. This was not observed in Prochilodus costatus tests because the linear

Table 1. The total length of the fish tested.

\begin{tabular}{ccccccc}
\hline \multirow{2}{*}{ Species } & \multicolumn{3}{c}{ Prolonged Speed } & \multicolumn{3}{c}{ Critical Speed } \\
\cline { 2 - 7 } & $\mathrm{N}$ & Mean & SD & N & Mean & SD \\
\hline Prochilodus costatus & 31 & 0.30 & 0.02 & 20 & 0.31 & 0.03 \\
Pimelodus maculatus & 32 & 0.24 & 0.02 & 25 & 0.23 & 0.03 \\
Leporinus reinhardti & 27 & 0.15 & 0.02 & 25 & 0.15 & 0.02 \\
\hline
\end{tabular}

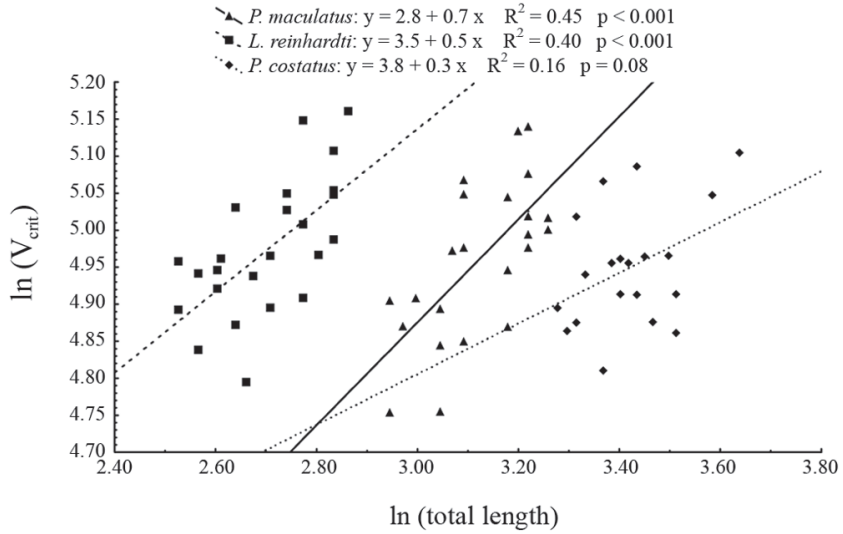

Fig. 1. The linear regression for natural logarithm of critical speed $(\mathrm{cm} / \mathrm{s})$ and natural logarithm of total length $(\mathrm{cm})$.

model was not significant $(\mathrm{P}=0.08)$ for the data. Leporinus reinhardti showed a higher speed for the same total length when compared to data from Pimelodus maculatus and Prochilodus costatus, the last one the slowest species (Fig. 1).

The comparison of critical curves between the studied species and data of species from other continents indicated the highest performance of the species evaluated (Fig. 2). Their speeds were higher than the values measured for good swimmers such as the salmonids Salmo salar and Oncorhynchus nerka.

Leporinus reinhardti showed the highest value of speed in prolonged mode $(12.5 \mathrm{BL} / \mathrm{s})$ and the fatigue time related to this speed was 10 minutes. Prochilodus costatus presented the lowest value for prolonged mode $(4 \mathrm{BL} / \mathrm{s})$ and the fatigue time for this was 160 minutes (Fig. 3).

The cumulative surviving proportion by Kaplan-Meier showed that a higher proportion of Pimelodus maculatus (43.75\%) can swim for periods longer than 200 minutes (Fig. 4), followed by Prochilodus costatus and Leporinus reinhardti. The survival functions were not significantly different, according to Gehan's Wilcoxon (Pimelodus maculatus $\mathrm{x}$ Prochilodus costatus: $\mathrm{p}=0.67$; Leporinus reinhardti x Pimelodus maculatus: $\mathrm{p}=0.75$; Leporinus reinhardti $\mathrm{x}$ Prochilodus costatus: $\mathrm{p}=0.91$ ).

Coefficients of optimal speed were obtained by the normal distribution, which was the best model for all data (Fig. 5). Analyses indicated that Leporinus reinhardti presented the best optimization of ground speed in prolonged mode when compared to the others studied species (Table 2).

\section{Discussion}

The results of critical and prolonged speeds indicated that Leporinus reinhardti was the fastest species for the same fish total length. Previous studies indicated that the genus Anostomidae could be a good swimmer. According to studies of Brazilian fish ladders, Anostomidae species can reach the 


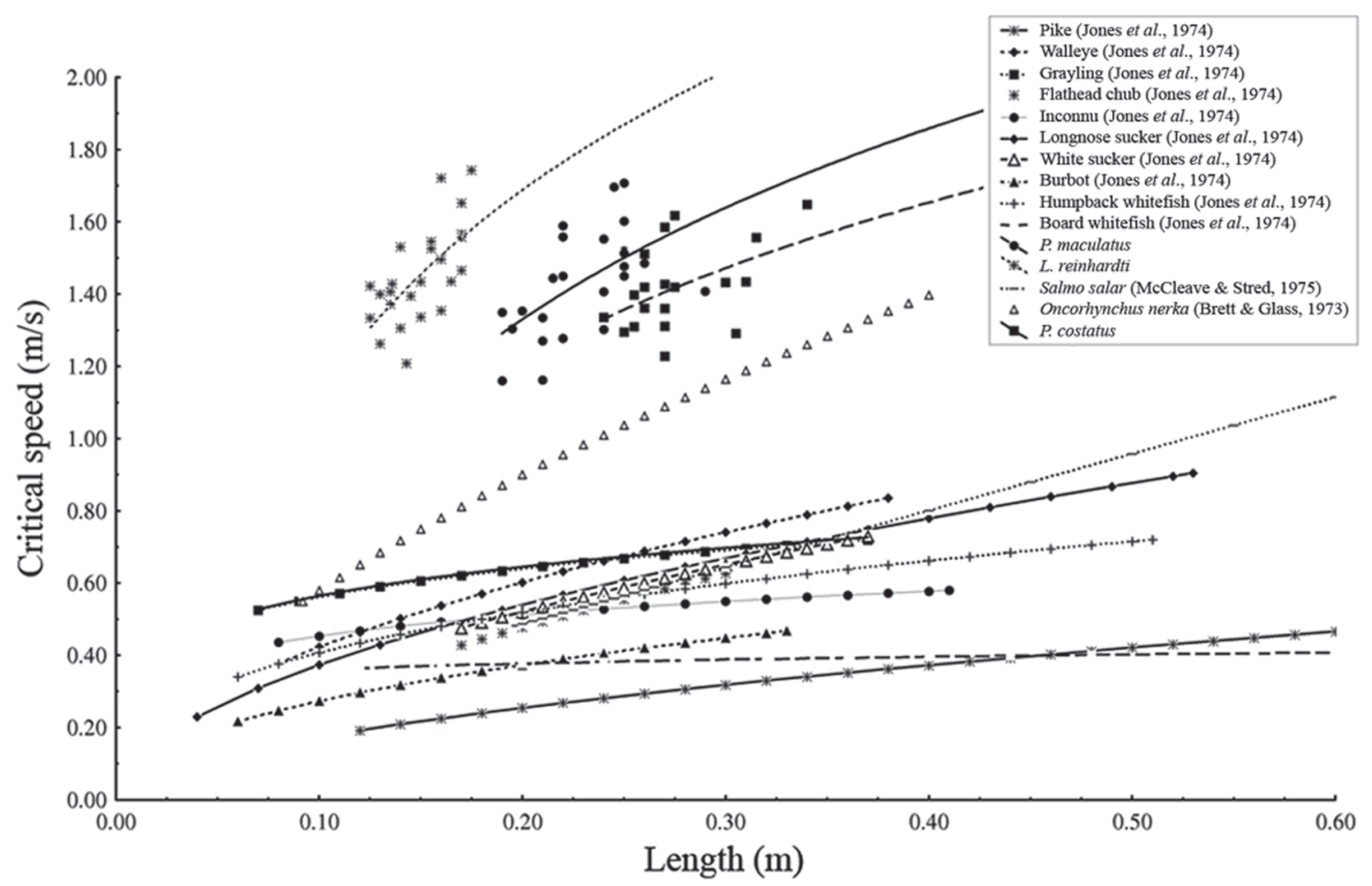

Fig. 2. Comparison of the critical curves for different species. DV and Dt for the test of Jones et al. (1974), McCleave \& Stred (1975) and Brett \& Glass (1973) are $10 \mathrm{~cm} / \mathrm{s}-10$ minutes, $5 \mathrm{~cm} / \mathrm{s}-5$ minutes and $10 \mathrm{~cm} / \mathrm{s}-60$ minutes, respectively.

upstream part of a channel without great difficulties (Makrakis et al., 2007) and the first scientific analysis of swimming capability in Brazil reports that Leporinus friderici could achieve the speed of $13 \mathrm{~m} / \mathrm{s}$ (Godoy, 1985).

Species of the same genus of the species tested are frequently found in Brazilian fish ladders but they present different behaviors from each other inside those structures (Makrakis et al., 2007 and Vono et al., 2004). This is mostly related to differences in swimming speeds, which are linked to differences in swimming locomotion and fish shape (Webb, 1994). Then, differences in swimming speeds are expected for characins and siluroids.

The prolonged swimming shows Leporinus reinhardti and Prochilodus costatus, whose speeds were similar in absolute values of speed, can swim faster than Pimelodus maculatus. The estimates of Pimelodus maculatus speed ranged from $0.95 \mathrm{~m} / \mathrm{s}$ to $1.23 \mathrm{~m} / \mathrm{s}$ for the first maturation size $(19 \mathrm{~cm})$. For Leporinus reinhardti in the first maturation size $(16 \mathrm{~cm})$, the prolonged mode interval varied from 1.12 $\mathrm{m} / \mathrm{s}$ to $1.68 \mathrm{~m} / \mathrm{s}$ and for $P$. costatus in first maturation size $(29$ $\mathrm{cm}$ ), it varied from 1.16 and $1.60 \mathrm{~m} / \mathrm{s}$.

Migrating fish overcoming speed barriers are often forced to swim at speeds greater than their maximum sustained speed and the successful passage in this case is related to the fish strategy of distance-maximizing in the speed barriers (Castro-Santos, 2005). Despite the differences in strategies, the migratory progression of different species can be equivalent regarding the river banks (Pavlov, 1989). During the reproductive migration, Prochilodus costatus often jumps and this behavior has been observed close to Brazilian dams (Capeleti \& Petrere, 2006). The failure to select an appropriate swim speed under speed barriers can be followed by the use of other locomotion patterns in order to swim upstream.

The high proportion of Pimelodus maculatus, which kept swimming after 200 minutes in the prolonged mode, may explain its large abundance in fish ladders already implemented in Brazil, overcoming the number of large-sized migratory species such as dourado (Salminus spp.) and curimba (Prochilodus spp.) (Fernandez et al., 2004; Vono et al., 2004; Bizzoto, 2006). However, it is important to point out that P. maculatus is frequently the most abundant species in southeastern Brazilian rivers, and its abundance in fish passes may also be reflecting the relative abundance of the populations downstream.

Curves of critical speed show a good performance of the three neotropical species evaluated. Differences in speed increments $(D V)$ and time increments $(D t)$ (Farlinger \& Beamish, 1977), may be taken in account when comparing results of different critical speed tests. However, differences in experimental procedures should support the highest values of speed for results of Jones et al. (1974) and a small difference (6\% lower) in speed of species studied by Brett \& Glass (1973).

The highest performance of the tested species was also observed in the prolonged mode. For the three species $(P$. 
maculatus, $L$. reinhardti and $P$. costatus), the time-to- $50 \%$ fatigue, when half of the fish were still swimming during the tests, was around 60 minutes. The fixed tests had different intervals of minimum and maximum prolonged tests but in general it ranged from $4 \mathrm{BL} / \mathrm{s}$ (minimum for $P$. costatus) to $10.5 \mathrm{BL} / \mathrm{s}$ (maximum for $L$. reinhardti). The fixed test for Oncorhynchus nerka which ranged from $3.1 \mathrm{BL} / \mathrm{s}$ to $3.9 \mathrm{BL} / \mathrm{s}$, showed a time-to-50\%-fatigue of 5 minutes (for the test of
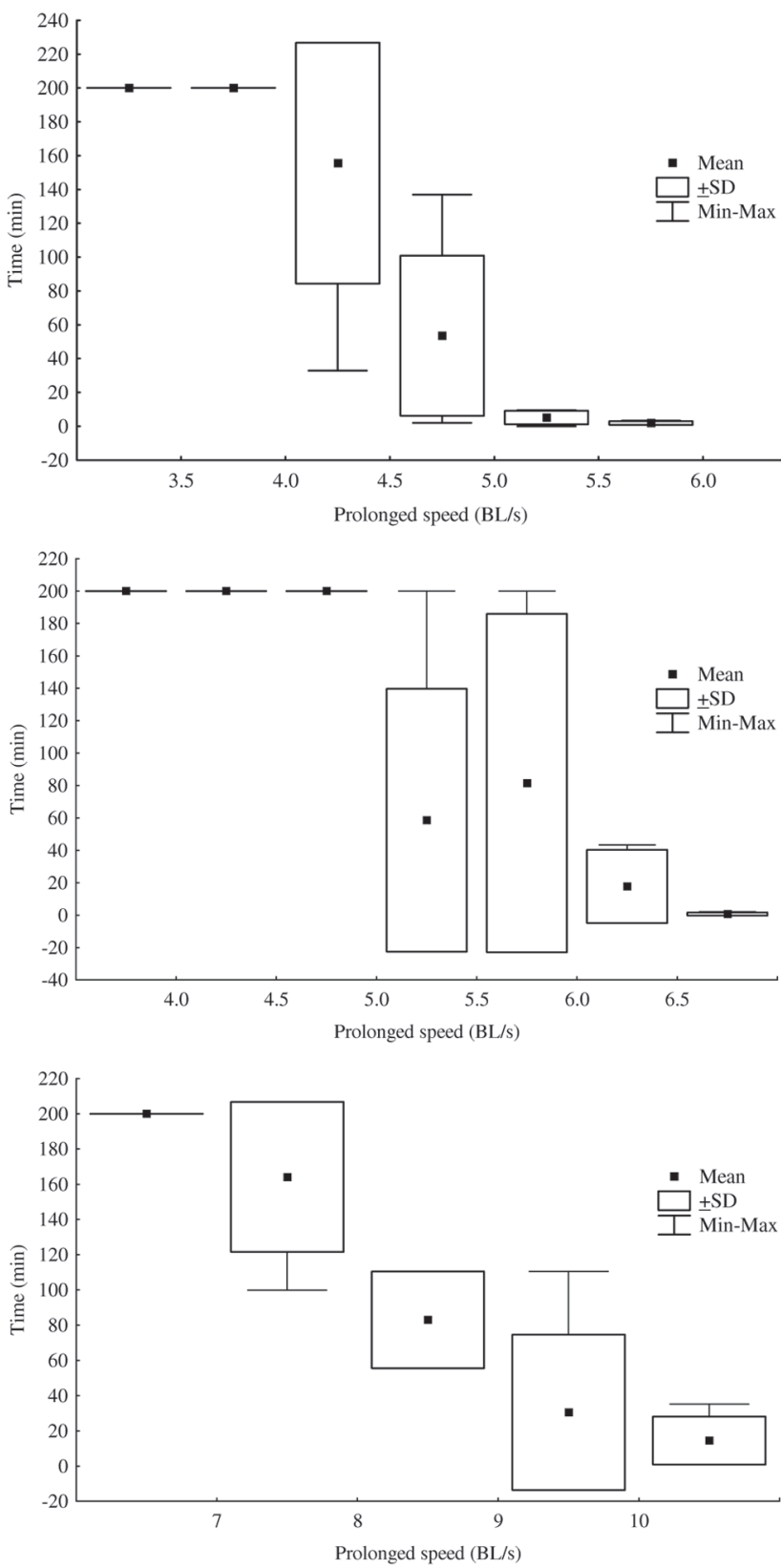

Fig. 3. Mean ( \pm standard deviation - SD; minimum - Min; and maximum - Max) values of time to fatigue ( $\mathrm{min}$ ) per speed class (lengths/s) for a) Prochilodus costatus b) Pimelodus maculatus and c) Leporinus reinhardti.

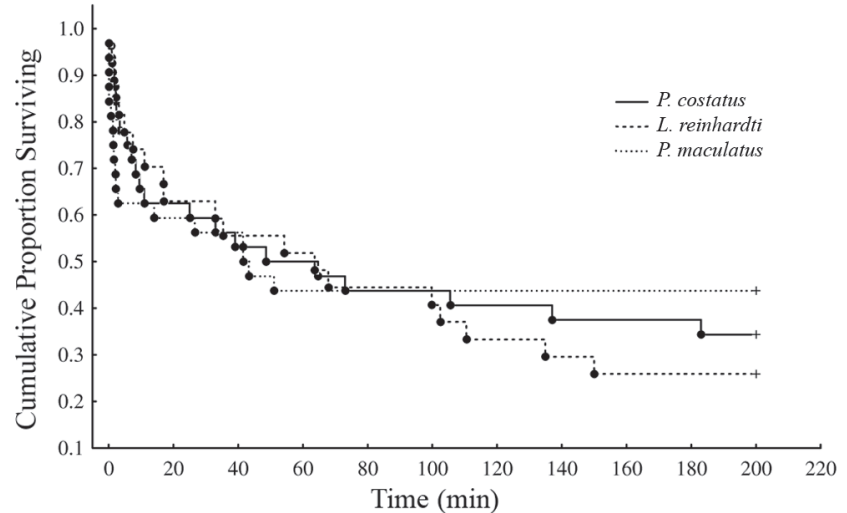

Fig. 4. The cumulative proportion surviving by Kaplan-Meier for the three neotropical species.

3.9 BL/s) and of 100 minutes (for the test of $3.1 \mathrm{BL} / \mathrm{s}$ ) (Brett, 1964).

The higher water temperature of neotropical aquatic systems might explain the good performance of their species (Santos et al., 2007), since this is a key factor related to the cost of swimming (Videler, 1993). The efficiency, defined as the rate of energy use per unit of mechanical power produced, decreases fast (Videler, 1993) at lower temperatures. Generally, within the thermal range of tolerance for a given species, prolonged speeds increase with temperature to a maximum (optimum temperature) and thereafter decline (Beamish, 1978).

The forced fish experiments in respirometer allowed us to compare the swimming ability of a large number of species in the world (Hammer, 1995), although it is limited to estimate the real speed occurred in the field (Peake, 2004; MallenCooper, 1992). Comparison between critical speed and free swimming in flumes has led to conclude the increased test provides an indication of the highest swimming speed that a fish can maintain for periods up to (and including) the

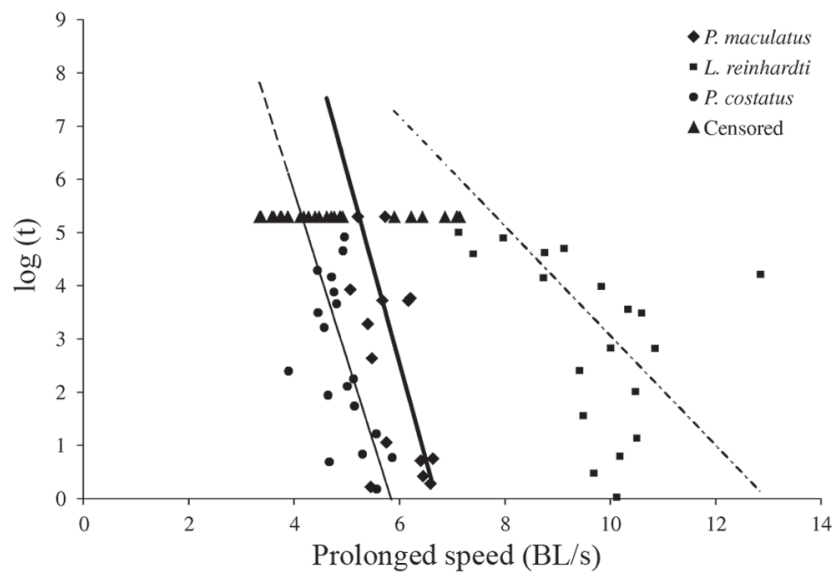

Fig. 5. Regressions for prolonged mode data (uncensored data) of the three neotropical species. 
Table 2. Endurance variables in prolonged modes for neotropical species. $\mathrm{V}_{\text {pmax }}$, maximum prolonged swim speed; $\mathrm{V}_{\text {goptp, }}$ predicted optimal ground speed; $N$, sample size, presented as fatigued (censored).

\begin{tabular}{lcccccc}
\hline Species & Distribution & $\begin{array}{c}\mathrm{V}_{\mathrm{pmax}} \\
(\mathrm{BL} / \mathrm{s})\end{array}$ & $a$ & $b$ & $\begin{array}{c}\mathrm{V}_{\text {goptp }} \\
(\mathrm{BL} / \mathrm{s})\end{array}$ & $N$ \\
\hline $\begin{array}{l}\text { Leporinus } \\
\text { reinhardti }\end{array}$ & Normal & 12.85 & 13.36 & -1.03 & 0.97 & $31(11)$ \\
$\begin{array}{l}\text { Pimelodus } \\
\text { maculatus }\end{array}$ & Normal & 6.63 & 24.13 & -3.6 & 0.28 & $27(8)$ \\
$\begin{array}{l}\text { Prochilodus } \\
\text { costatus }\end{array}$ & Normal & 5.85 & 18.27 & -3.13 & 0.32 & $30(14)$ \\
\hline
\end{tabular}

magnitude of the time interval used in the protocol (Bunt et al., 1999; Peake, 2004).

Although forced experiments can provide higher fish speeds than results of volitional tests, the strategies of swim speed optimization might fail in confined apparatus. The optimum ground speeds in prolonged mode for the three studied species, estimated by respirometer data, were lower than those found in volitional tests of four migratory fish in North America. The slowest species, the American shad, showed $1 \mathrm{BL} / \mathrm{s}$ as optimum ground speed (Castro-Santos, 2005) while the fastest neotropical species, Leporinus reinhardti, swam $0.97 \mathrm{BL} / \mathrm{s}$. However, it is not clear if the respirometer also underestimated the maximum prolonged speed. Regarding this speed, L. reinhardti swam faster (12.85 $\mathrm{BL} / \mathrm{s}$ ) than Walleye whose speed was $10.6 \mathrm{BL} / \mathrm{s}$ in the prolonged mode (Castro-Santos, 2005).

Differences in results of the forced experiments and the volitional tests are related to differences in energetic costs associated with confined and unconfined swimming (Peake, 2004). The test sections of respirometers have elements to produce a rectilinear front of statistically uniform turbulence (Brett, 1964). It also reduces the turbulence over the fish chamber from $2 \%$ to $0.7 \%$ (Brett, 1964). The level of turbulence affects the costs of swimming and differences between the forced and spontaneous swimming models can lead to different estimates of its cost (Enders, 2003).

Despite the accuracy of speeds from forced tests, results of this study provide us support to know the relative swimming ability of Brazilian native species, which has been considered one of main bottlenecks to establish broad guidelines regarding the most suitable fish passes designs (Quirós, 1989; Clay, 1995; Marmulla, 2001). Especially information about prolonged mode swimming can be applied in the design of new fish passes. However, many other physical parameters, such as turbulence and noise levels, may guide the fish behavior inside fish ladders. Therefore, speed analyses in fish ladder design should be considered as the first step of a comprehensive analysis of neotropical fish suitability.

\section{Acknowledgments}

We are grateful to CEMIG for the logistics and financial support. Special thanks to the students César Augusto Muniz
Toledo and Lívia Duarte Ventura Melo who helped us with the experimental tests; and to the workers Geraldo Garcia, Vicente Pimenta and Paulo Roberto who helped us with the construction of the experimental apparatus.

\section{Literature Cited}

Agostinho, A. A., E. E. Marques, C. A. Agostinho, D. A. Almeida, R. J. Oliveira \& J. R. B. Melo. 2007. Fish ladder of Lajeado Dam: migrations on one-way routes? Neotropical Ichthyology, 5: 121-130.

Alves, C. B. M. 2007. Evaluation of fish passage through the Igarapé Dam fish ladder (rio Paraopeba, Brazil), using marking and recapture. Neotropical Ichthyology, 5: 233-236.

Anderson, J. J. 1988. Diverting migrating fish past turbines. The Northwest Environmental Journal, 4: 109-128.

Baigún, C. R. M., J. M. Nestler, N. O. Oldani, R. A., Goodwin \& L. J. Weber. 2007. Can north american fish passage tools work for South american migratory fishes? Neotropical Ichthyology, 5: 109-119

Beamish, F. W. H. 1978.Swimming capacity. Pp.101-187. In. Hoar, W. S. \& D. J. Randall (Ed.). Fish Physiology. New York, Academic Press, 576p.

Bizotto, P. M. 2006. Trânsito de peixes na escada da UHEIgarapava, Rio Grande, Alto Paraná. Unpublished Dissertation, Pontifícia Universidade Católica de Minas, Belo Horizonte, 52p.

Brett, J. R. 1964. The respiratory metabolism and swimming performance of young Sockeye Salmon. Journal of the Fisheries Research Board of Canada, 21: 1183-1226.

Brett, J. R. 1967. Swimming performance of Sockeye Salmon (Oncorhynchus nerka) in relation to fatigue time and temperature. Journal of the Fisheries Research Board of Canada, 21: 1731-1741.

Brett, J. R. \& N. R. Glass. 1973. Metabolic rates and critical swimming speeds of sockeye salmon (Oncorhynchus nerka) in relation to size and temperature. Journal of the Fisheries Research Board of Canada 30: 379-387.

Bunt. C. M., C. Katopodis \& R. S. McKinley 1999. Attraction and passage efficiency of white suckers and smallmouth bass by two Denil fishways. North American Journal of Fisheries Management 19: 793-803.

Capeleti, A. R. \& M. Petrere Jr. 2006. Migration of the curimbata Prochilodus lineatus (Valenciennes, 1836) (Pisces, Prochilodontidae) at the waterfall "Cachoeira de Emas" of the Mogiguaçu river São Paulo, Brazil. Brazilian Journal of Biology, 66: 651659 .

Carvalho-Costa, L. F., T. Hatanaka \& P. M. Galetti Jr. 2008. Evidence of lack of population substructuring in the Brazilian freshwater fish Prochilodus costatus. Genetics and Molecular Biology, 31: 377-380.

Castro-Santos, T. 2005. Optimal swim speeds for traversing velocity barriers: an analysis of volitional high-speed swimming behavior of migratory fishes. The Journal of Experimental Biology. 20: 421-432

Cech, J. J. 1990 . Respirometry. Pp. 335-362. In C. B. Schreck, and P. B. Moyle (Eds). Methods for Fish Biology. Bethesda, Maryland: American Fisheries Society.

Clay, C. H. 1995. Design of fishways and other fish facilities. Boca Raton, CRC Press, 248p

Colosimo, E. A. \& S. R. Giolo. 2006. Análise de sobrevivência aplicada. São Paulo: Edgard Blucher 392p. 
Enders, E. C., D. Boisclair \& A. G. Roy. 2003. The effect of turbulence on the cost of swimming for juvenile Atlantic salmon (Salmo salar). Canadian Journal of Fisheries and Aquatic Sciences 60: 1149-1160.

Farlinger, S. \& F. W H. Beamish. 1977. Effects of time and velocity increments on the critical swimming speed of Largemouth Bass (Micropterus salmoides). Transaction american fisheries society, 106: 436- 439.

Fernandez, D. R., A. A. Agostinho \& L. M. Bini. 2004. Selection of an experimental fish ladder located at the dam of the Itaipu Binacional, Paraná River, Brazil. Brazilian Archives of Biology and Technology, 47: 579-586.

Fernandez, D. R., A. A. Agostinho, L. M. Bini \& F. M. Pelicice. 2007. Diel variation in the ascent of fishes up an experimental fish ladder at Itaipu Reservoir: fish size, reproductive stage and taxonomic group influences. Neotropical Ichthyology, 5:215-222.

Hammer, C. 1995. Fatigue and exercise tests with fish. Comparative Biochemistry and Physiology, 112: 1-20.

Jones, D. R., J. W. Kiceniuk \& O. S. Bamford. 1974. Evaluation of the swimming performance of several fish species from the Mackenzie River. Journal of the Fisheries Research Board of Canada, 31: 1641-1647.

Katopodis, C. 1992. Introduction to Fishway Design. Winnipeg: Freshwater Institute, 67p.

Makrakis, S., L. C. Gomes, M. C. Makrakis, D. R. Fernandez \& C. S. Pavanelli. 2007. The Canal da Piracema at Itaipu Dam as a fish pass system. Neotropical Ichthyology, 5:185-195.

Mallen-Cooper, M. 1992. Swimming ability of juvenile Australian bass, Macquaria novemaculeata (Steindachner), and juvenile barramundi. Lates calcarifer (Bloch) in an experimental fishway. Australian Journal of Marine and Freshwater Research, 43: 823-834.

Marmulla, G. 2001. Dams, fish and fisheries. Opportunities, challenges and conflict resolution. FAO Fisheries Technical Paper. No. 419. Rome, FAO. 166p.

McCleave, J. D. \& K. Stred. 1975. Effect of dummy telemetry transmitters on stamina of Atlantic salmon (Salmo salar) smolts. Journal of the Fisheries Research Board of Canada, 32: 559-563.

Pavlov, D. S. 1989. Structures assisting the migrations of nonsalmonid fish: USSR. FAO, 97p.

Peake, S. 2004. An evaluation of the use of critical swimming speed for determination of culvert water velocity criteria for smallmouth bass. Transaction of the American Fisheries Society, 133: $1472-1479$.
Pompeu, P. S. \& C. B. Martinez. 2006. Variações temporais na passagem de peixes pelo elevador da usina Hidrelétrica de Santa Clara, rio Mucuri, leste brasileiro. Revista Brasileira de Zoologia, 23: 340-349.

Quirós, R. 1989. Sctructures assisting the migrations of nonsalmonid fish: Latin America. Copescal Technical Paper n. 5, Roma: FAO, 141p.

Rae, W. H. \& A. Pope. 1984. Low-speed wind tunnel testing. New York, John Wiley \& Sons, 534p.

Rizzo, E., Y. Sato, R. M. A. Ferreira, H. Chiarini-Garcia \& N. Bazzoli. 1996. Reproduction of Leporinus reinhardti (Pisces: Anostomidae) from the Três Marias Reservoir, São Francisco River, Minas Gerais, Brazil. Ciência e Cultura, 48: 189-192.

Santos, H. A. 2007. A influência da capacidade natatória de peixes neotropicais no projeto hidráulico de mecanismos de transposição. Unpublished Ph.D. Dissertation, Universidade Federal de Minas Gerais, Belo Horizonte. 179p.

Santos, H. A, P. S. Pompeu \& C. B. Martinez. 2007. Swimming performance of the migratory Neotropical fish Leporinus reinhardti (Characiformes: Anostomidae). Neotropical Ichthyology, 5: 139-146.

Santos, H. A., P. S. Pompeu, G. S. Vicentini \& C. B. Martinez. 2008. Swimming performance of the freshwater neotropical sh: Pimelodus maculatus Lacepède, 1803. Brazilian Journal of Biology, 68: 433-439.

StatSoft, Inc. 2007. STATISTICA (data analysis software system), version 8.0. www.statsoft.com.

Videler, J. J. 1993. Fish swimming. 1 ed.. Londres: Chapman \& Hall, 260p.

Vono, V., P. M. Bizzotto, H. P. Godinho, A. L. Godinho \& B. Kynard. 2004. Fish passage at the Igarapava Fish Ladder, River Grande, Brazil. Pp. 1-5. In: Annals of the International Congress on the Biology of Fish - Tropical Hotel Resort. Manaus, American Fisheries Society.

Webb, P. W. 1975. Hydrodynamics and energetics of fish propulsion. Bulletin of the fisheries research board of Canada, 190: 1-158.

Webb, P. W. 1994.The biology of fish swimming. Pp.45-62. In. Mechanics and physiology of animal swimming. Cambridge University Press, Cambridge, 250p.

Welcomme, R. L. 1985. River fisheries. FAO Fisheries, 330p.

Submitted March 15, 2012 Accepted September 10, 2012 